Sri Lanka J. Aquat. Sci. 20 (1) (2015): 47-58

\title{
Spatial differences in the growth rates of Pocillopora damicornis associated with sedimentation rate and light intensity at Polhena patchy reef, southern Sri Lanka
}

\author{
W.A.A.Upasantha Kumara ${ }^{1 *}$, P.B.T. Pradeep Kumara ${ }^{2}$ and P.R.T. \\ Cumaranatunga ${ }^{3}$ \\ ${ }^{1}$ Faculty of Fisheries and Marine Science, Ocean University of Sri Lanka, \\ Mahawela Road, Tangalle, Sri Lanka
}

${ }^{2}$ Department of Oceanography and Marine Geology, Faculty of Fisheries and Marine Sciences and Technology, University of Ruhuna, Matara, Sri Lanka

${ }^{3}$ Department of Fisheries and Aquaculture, Faculty of Fisheries and Marine Sciences and Technology, University of Ruhuna, Matara, Sri Lanka

Corresponding author (E-mail: waaukumara@gmail.com)

\begin{abstract}
Near shore patchy reef located at the leeward side of the fringing reef at Polhena was surveyed to evaluate spatial patterns of growth rates of Pocillopora damicornis. This study was carried out at three locations of the reef; front, side and back from June to November in 2004. Three sites were selected from each location considering the depth (surface, middle, and bottom). Forty five colonies of $P$. damicornis which were approximately of the same size were studied. Temperature, dissolved oxygen, $\mathrm{BOD}_{5}$, salinity, $\mathrm{pH}$, soluble reactive phosphorous, turbidity and light intensity of each site were measured fortnightly and their mean values were $28.06 \pm 0.24{ }^{\circ} \mathrm{C}$, $8.78 \pm 0.15 \mathrm{mg} \mathrm{L}^{-1}, 1.40 \pm 0.32 \mathrm{mg} \mathrm{L}^{-1}, 31.91 \pm 3.49 \mathrm{mg} \mathrm{L}^{-1}, 8.12 \pm 0.04,8.12 \pm$ $0.01,20.21 \pm 2.05 \mu \mathrm{g} \mathrm{L}^{-1}, 5.78 \pm 1.20 \mathrm{NTU}$, and $49.17 \pm 1.97$ Lux respectively. Sediments in each site were collected using traps and mean overall sedimentation rate for the experimental period was $45860.6 \pm 3364.2 \mathrm{ml} \mathrm{m}^{-2}$ day $^{-1}(2620.6 \pm 192.2$ $\mathrm{g} \mathrm{m}^{-2}$ day $\left.^{-1}\right)(\mathrm{n}=36)$. Growth of coral colonies, which was measured as linear skeletal extension rate (LSER), was $0.15 \pm 0.01 \mathrm{~mm} \mathrm{day}^{-1}$. Significant differences in mean light intensity, mean sediment volume, and LSER of coral colonies were observed among different sites. The highest sedimentation rate $94818.2 \pm 6981.5 \mathrm{ml}$ $\mathrm{m}^{-2}$ day $^{-1}\left(5418.2 \pm 398.9 \mathrm{~g} \mathrm{~m}^{-2} \mathrm{day}^{-1}\right)$ and the lowest LSER of the colonies $(0.05 \pm$ $0.01 \mathrm{~mm} \mathrm{day}^{-1}$ ) were observed at back bottom site. The highest LSER was observed at front surface $\left(0.23 \pm 0.01 \mathrm{~mm} \mathrm{day}{ }^{-1}\right)$. LSER showed a significant negative correlation $\left(\mathrm{R}^{2}=0.59\right)$ with increased sedimentation rate and low light intensity.
\end{abstract}


Back bottom site of the patchy reef was having comparatively unfavorable conditions for the growth of corals that were subjected to more environmental stress than the corals in other sites of the reefs.

Keywords: coral growth; linear skeletal extension rate; light intensity; mean sedimentation rate; Polhena coral reef

\section{Introduction}

Changes in variety of environmental parameters in seawater have impacts on growth of corals. Effects of the changes in physico-chemical parameters in seawater for coral growth have been widely studied, and it has been documented that the higher levels of sedimentation, low intensity of light, decreased salinity, increased temperature, changes in $\mathrm{pH}$ and low levels of dissolved oxygen (DO) can reduce the growth rate of corals (Buddemeier and Kinzie 1976). The proximity of rivers to coral reefs is a very important determinant of the condition of coral reefs because they are not only the principal sources of sediments, nutrients and salinity stress along tropical coast lines but also the sources of range of other substances that may impact corals and reef associated organisms (Goreau 1992; Wilkinsion and Buddemeier 1994). Corals may be eliminated altogether in areas close to river mouths where large amounts of sediments enter the sea (Veron 1986). Light plays a major role in providing the energy for photosynthetic activity of the zooxanthellae, which consequently determines where corals may grow (Muscatine 1990).

Fine particles of sediments have negative effects on growth of corals. Sediments can smother corals and reduce light penetration through water column to the coral zooxanthellae thereby stressing corals and reducing their growth (Patterson et al. 1991). Corals waste their energy which can be used for their growth (Crossland 1980), to remove sediments coming into contact with their bodies (Charuchinda and Hyllerg 1984). Therefore, this study hypothesized that the Pocillopora damicornis has slower linear skeletal extension rate (LSER) at the places where there is higher sedimentation rate than at the places where there is lower sedimentation rate.

The objectives of the present study were to compare the linear skeletal extension rate (growth rate) of $P$. damicornis with respect to the places they exist in a patchy reef located at Polhena and to examine whether there is any association between the LSER and physico-chemical parameters of the surrounding seawater during the south-west monsoon season between June and November. This is the first study that has considered physico-chemical parameters around a patchy-reef considering several depths. The finding of this study provides a conceptual aid to assess the changes likely to occur on corals growth in response to changing coastal water quality.

\section{Materials and Methods}

Study was conducted from June to November 2004, at Polhena fringing reef in southern Sri Lanka (Figure 1). This reef is located $2 \mathrm{~km}$ north of Matara in close proximity to the Nilwala river mouth. This reef consists of patches of coral reefs 
covering 1 ha or more and it is situated just off the beach $(50 \mathrm{~m}-100 \mathrm{~m}$ from the shore) at a depth of nearly 1-3 $\mathrm{m}$ of water (Ohman et al. 1998). Part of Polhena reef is covered by sand carried by the Nilwala river and live corals were more common at the eastern end of the reef (Rajasuriya et al. 1998).

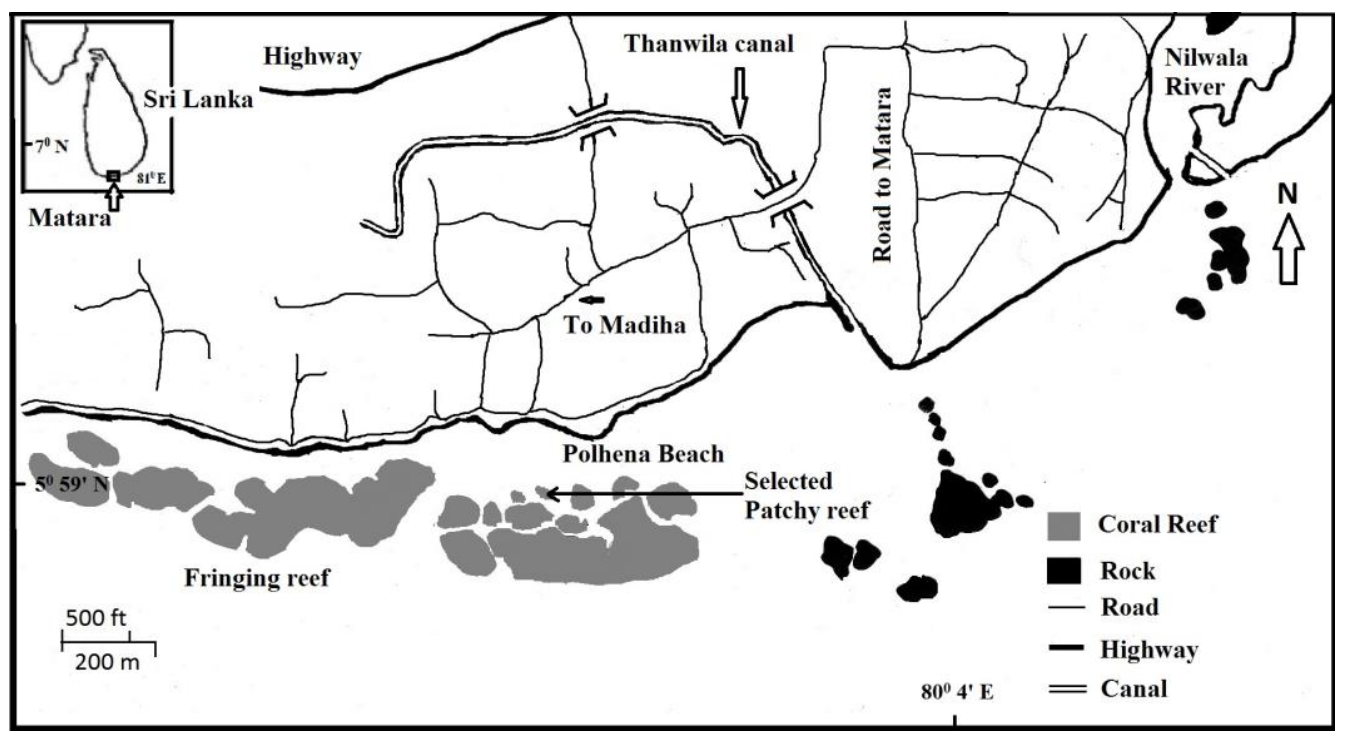

Figure 1. Map showing the patchy reef studied at Polhena fringing reef (Modified after Fairoz 2006).

Three locations in the front, side and back of the patchy reef were selected at random for the study. Front side was the area where off-shore waves hit the reef while side location was the parallel edge of the patchy reef to the off-shore wave and back location was the lee-ward side of the patchy reef. In each location, three sites (surface, middle and bottom) were considered according to the depth. Surface site always represented the surface of the patchy reef, middle site was at a depth of approximately $1 \mathrm{~m}$ and bottom site was at the bottom of the reef approximately at a depth of $2 \mathrm{~m}$ (Figure 2). Relatively small colonies were randomly selected in each site and tagged with a plastic wire, about $3 \mathrm{~cm}$ from the tips of branch situated perpendicular to the longest axis of the colony. A total of 45 P. damicornis colonies comprising five colonies in each site were tagged initially. Diameter of each colony was measured once in every month at all sites along the longest axis of the colony to the nearest $\mathrm{mm}$, with a plastic vernier caliper in order to calculate linear skeletal extension rate (LSER). Actual linear skeletal extension rate was considered as half of LSER.

\section{Measurements of physico-chemical parameters.}

During every sampling occasion temperature, turbidity, $\mathrm{pH}$, salinity, DO, biological oxygen demand $\left(\mathrm{BOD}_{5}\right)$, concentration of soluble reactive phosphorous, light intensity and sediment deposition rate were determined in each site. Water samples were taken in to $1 \mathrm{~L}$ plastic bottles and temperature, $\mathrm{pH}$ and turbidity were 
measured in situ using a mercury thermometer, portable $\mathrm{pH}$ meter (Model 666140 from an environmental multiprobe of W.P.M. Instruments Ltd. UK) and digital portable 2100P Hatch turbidity meter. Salinity was measured in situ using a battery operated digital portable Orion conductivity and salinity meter (model 140). DO and $\mathrm{BOD}_{5}$ were measured using the Winkler's method (Makerenth et al. 1978). Water samples for measurement of DO were fixed on site. Soluble reactive phosphorous (ortho-phosphate) was determined using ascorbic acid method (Makerenth et al. 1978). Light intensity at each site was measured using under water irradia meter (KAHL scientific instrument corp. EL. CAJON, CALIF.92022 USA, Serial No2101). Sediments were collected using three traps (internal diameter-50 mm; height$250 \mathrm{~mm}$ ) installed at each site keeping the base of the trap $10 \mathrm{~cm}$ above the substratum. To collect the sediments at 2 weekly intervals, all traps were transported to the laboratory in a cool box and sediments were sieved using a $0.01 \mathrm{~mm}$ sieve and sieved particles were allowed to dry in a dryer. Each sample was dried to a constant weight and the volume and the weight of sediments were measured. Volume of the sediments was measured using a measuring cylinder, and weight of the sediments was measured using an analytical balance.

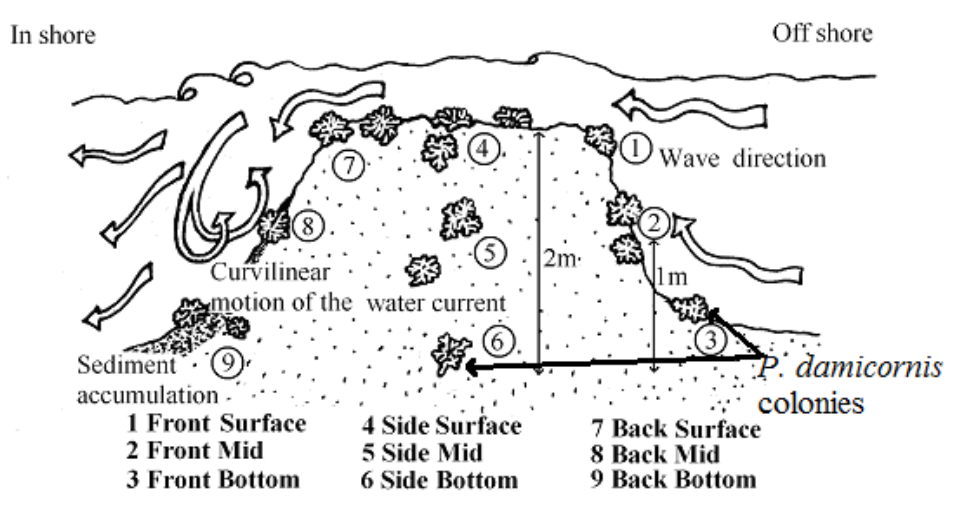

Figure 2. Schematic representation of the patchy reef showing the sites (1 to 9) selected from three locations (front, side, and back) for the study.

\section{Statistical analysis}

Growth rate and physico-chemical data were compared using two-way ANOVA. A post-hoc Tukey's test was carried out if the interaction term (location * site) of the model was significant (Sokal and Rohlf 1969). Homogeneity of variance and normality of residuals were verified respectively with Cochran's $\mathrm{C}$ and predicted and residual plots. The main objective was to compare mean growth rate (LSER) in P. damicornis, and mean values of physico-chemical parameters among different sites of the patchy-reef locations. Correlation coefficient was tested to assess the association between mean growth rate of $P$. damicornis $\left(\mathrm{mm} \mathrm{week}^{-1}\right)$ and physico-chemical parameters. Statistica software was used to statistical analyzing. The similarities in the physico-chemical data and the LSER of $P$. damicornis among sites were analyzed using PRIMER-version 6.2.13 (Plymouth Routines in 
Multivariate Ecological Research) for non-parametric tests. Square root transformed values of physico-chemical values and LSER values were used to analyze the similarities among sites performing Multi Dimensional Scaling (MDS) with BrayCurtis similarity matrix and cluster analysis.

\section{Results}

Overall mean values and ranges of parameters studied during the study period are given in Table 1.

Table 1. Overall-mean \pm standard error (SE) of physico-chemical parameters during 12 sampling occasions and linear skeletal extension rate (LSER) during 6 sampling occasions from June to November, 2004. All the data from nine sites from June to November were combined together to calculate overall mean values for the season.

\begin{tabular}{|c|c|c|c|}
\hline \multirow{2}{*}{ Parameter } & \multirow{2}{*}{$\begin{array}{l}\text { Overall Mean } \\
\quad \pm S E\end{array}$} & \multicolumn{2}{|c|}{ Range } \\
\hline & & Lowest (month) & Highest (month) \\
\hline Temperature $\left({ }^{\circ} \mathrm{C}\right)$ & $28.1 \pm 0.19$ & 26.5 (July) & 29.5 (November) \\
\hline $\mathrm{DO}\left(\mathrm{mg} \mathrm{L}^{-1}\right)$ & $8.8 \pm 0.07$ & 7.0 (October) & 7.6 (July) \\
\hline $\mathrm{BOD}\left(\mathrm{mgL}^{-1}\right)$ & $1.4 \pm 0.05$ & 0.9 (November) & 1.6 (August) \\
\hline Salinity $\left(\mathrm{mgL}^{-1}\right)$ & $31.9 \pm 0.58$ & 27.3 (July) & 35.2 (August) \\
\hline $\mathrm{pH}$ & $8.1 \pm 0.01$ & 8.1 (October) & 8.2 (July) \\
\hline $\begin{array}{l}\text { Reactive phosphorous } \\
* 10^{-3}\left(\mathrm{~m} \mathrm{~L} \mathrm{~L}^{-1}\right)\end{array}$ & $20.21 \pm 2.05$ & 8.46 (October) & 31.51 (July) \\
\hline Turbidity (NTU) & $5.78 \pm 0.39$ & 3.84 (July) & 8.75 (August) \\
\hline Light intensity (Lux) & $49.2 \pm 0.32$ & 49.0 (August) & 549.5 (November) \\
\hline $\begin{array}{l}\text { Sedimentation rate } \\
\left(\mathrm{ml} \mathrm{m}^{-2} \text { day }^{-1}\right)\end{array}$ & $\begin{array}{c}45860.6 \pm \\
3364.2 \\
(2620.6 \pm \\
192.2 \mathrm{~g} \mathrm{~m}^{-2} \\
\left.\text { day }^{-1}\right)\end{array}$ & $\begin{array}{l}37389.9 \\
\text { (November) } \\
\left(2199.4 \mathrm{~g} \mathrm{~m}^{-2} \text { day }^{-1}\right)\end{array}$ & $\begin{array}{l}54133.3 \\
\text { (July) } \\
\left(3102.2 \mathrm{~g} \mathrm{~m}^{-2} \text { day }^{-1}\right)\end{array}$ \\
\hline LSER $\left(m m\right.$ day $\left.^{-1}\right)$ & $0.15 \pm 0.01$ & 0.10 (July) & 0.17 (October) \\
\hline $\begin{array}{l}\text { Actual LSER (mm } \\
\left.\text { day }^{-1}\right)\end{array}$ & $0.08 \pm 0.007$ & 0.05 (July) & 0.09 (October) \\
\hline
\end{tabular}

Among the 45 colonies of $P$. damicornis tagged, five colonies were damaged during the study period and 40 colonies were used to determine LSER. There was a significant difference in the mean LSER among sites. The LSER of the back bottom site of the patchy reef (site 9) $\left(0.055 \pm 0.005 \mathrm{SE} \mathrm{mm} \mathrm{day}^{-1}\right)$ was significantly lower and about $25 \%$ slower than those of the corals in the front surface $(0.228 \pm 0.005$ $\mathrm{mm}$ day $\left.^{-1}\right)$, the side surface $\left(0.218 \pm 0.017 \mathrm{~mm} \mathrm{day}^{-1}\right)$, the back surface $(0.226 \pm$ $\left.0.016 \mathrm{~mm} \mathrm{day}^{-1}\right)$, and the back mid $\left(0.209 \pm 0.025 \mathrm{~mm} \mathrm{day}^{-1}\right)(\mathrm{MSE}=0.0038, \mathrm{df}=$ 31 , corresponding $\mathrm{p}$ values $=0.032,0.014,0.008$, and 0.009) (Table 2, Figure 3). Moreover, the LSER at the back bottom site was about one third of that of the side 
mid site $\left(0.196 \pm 0.039 \mathrm{~mm} \mathrm{day}^{-1}\right)$ of the patchy reef $(\mathrm{p}=0.01)$. In addition, the LSER at the side bottom site $\left(0.084 \pm 0.019 \mathrm{~mm} \mathrm{day}^{-1}\right)$ was about half of that at the back surface $\left(0.226 \pm 0.061 \mathrm{~mm} \mathrm{day}^{-1}\right)(\mathrm{MSE}=0.0038, \mathrm{df}=31, \mathrm{p}=0.04)$ (Table 2, Figure 3). There were no statistical differences in mean overall values of physicochemical parameters between the locations, sites and interaction terms except for sediment volume and light intensity ( $p>0.05)$ (Table 2).

Mean overall sediment volume at the back bottom site $(94818.2 \pm 6981.5 \mathrm{ml}$ $\mathrm{m}^{-2}$ day $^{-1}=5418.2 \pm 398.9 \mathrm{~g} \mathrm{~m}^{-2}$ day $\left.^{-1}\right)$ was significantly higher and about two times as that of all the other sites namely the front surface $\left(37672.7 \pm 3641.6 \mathrm{ml} \mathrm{m}^{-2}\right.$ day $\left.^{-1}\right)$, the front mid $\left(35763.0 \pm 5308.5 \mathrm{ml} \mathrm{m}^{-2}\right.$ day $\left.^{-1}\right)$, the front bottom $(43527.3 \pm 5739.1$ $\mathrm{ml} \mathrm{m}^{-2}$ day $\left.^{-1}\right)$, the side surface $\left(38563.6 \pm 3614.0 \mathrm{ml} \mathrm{m}^{-2}\right.$ day $\left.^{-1}\right)$, the side mid (38563.6 $\pm 4777.4 \mathrm{ml} \mathrm{m}^{-2}$ day $\left.^{-1}\right)$, the side bottom $\left(46581.8 \pm 3411.9 \mathrm{ml} \mathrm{m}^{-2} \mathrm{day}^{-1}\right)$, the back surface $\left(40090.9 \pm 3679.2 \mathrm{ml} \mathrm{m}^{-2} \mathrm{day}^{-1}\right)$, and the back mid $\left(37163.6 \pm 8667.0 \mathrm{ml} \mathrm{m}^{-2}\right.$ day $\left.^{-1}\right)(\mathrm{p}=0.001, \mathrm{MSE}=444.66, \mathrm{df}=27)$. Overall, there were huge accumulations of sediments at all the bottom sites when compared with other sites (Figure 3).

Mean overall light intensity was significantly different among sites (Table 2, Figure 3). The lowest value was recorded at the back bottom site (site 9) (47.3 \pm $0.03 \mathrm{Lux})$ and the highest at the front surface (site 1) $(52.0 \pm 0.48 \mathrm{Lux})$. All of the bottom sites had low light intensities while the surface sites had high light intensities as expected (Figure 3). However, there was no significant difference in mean light intensity between sites.

Table 2. Results of two way ANOVA for linear skeletal extension rate (LSER) and physico-chemical parameters for each site during study period. ( $\mathrm{SS}=$ sum of square; $\mathrm{df}=$ degrees of freedom; $\mathrm{MS}=$ Mean square; $\mathrm{F}=\mathrm{F}$ value; $\mathrm{p}=$ the level of significance. $*$ - significant at $\mathrm{p}<0.05)$.

\begin{tabular}{|c|c|c|c|c|c|}
\hline Source/Parameter & SS & $\mathrm{df}$ & MS & $\mathrm{F}$ & $\mathrm{p}$ \\
\hline \multicolumn{6}{|l|}{$\overline{L S E R}\left(m m\right.$ day $\left.^{-1}\right)$} \\
\hline Location & 0.002 & 2 & 0.001 & 0.282 & 0.756 \\
\hline Site & 0.110 & 2 & 0.055 & 14.726 & $0.001 *$ \\
\hline Location*Site & 0.025 & 4 & 0.006 & 1.649 & 0.187 \\
\hline Error & 0.116 & 31 & 0.004 & & \\
\hline \multicolumn{6}{|c|}{ Light intensity (Lux) } \\
\hline Location & 0.541 & 2 & 0.271 & 2.022 & 0.152 \\
\hline site & 123.462 & 2 & 61.731 & 461.037 & $0.001 *$ \\
\hline Location*site & 0.156 & 4 & 0.039 & 0.291 & 0.881 \\
\hline Error & 3.615 & 27 & 0.134 & & \\
\hline \multicolumn{6}{|c|}{ Sedimentation rate $\left(\mathrm{ml} \mathrm{m}^{-2}\right.$ day $\left.^{-1}\right)$} \\
\hline Location & $2.41 * 10^{9}$ & 2 & $1.205 * 10^{9}$ & 10.454 & $0.001 *$ \\
\hline site & $4.50 * 10^{9}$ & 2 & $2.250 * 10^{9}$ & 19.519 & $0.001 *$ \\
\hline Location*site & $4.241 * 10^{9}$ & 4 & $1.060 * 10^{9}$ & 9.199 & $0.001 *$ \\
\hline Error & $3.112 * 10^{9}$ & 27 & $1.152 * 10^{8}$ & & \\
\hline
\end{tabular}



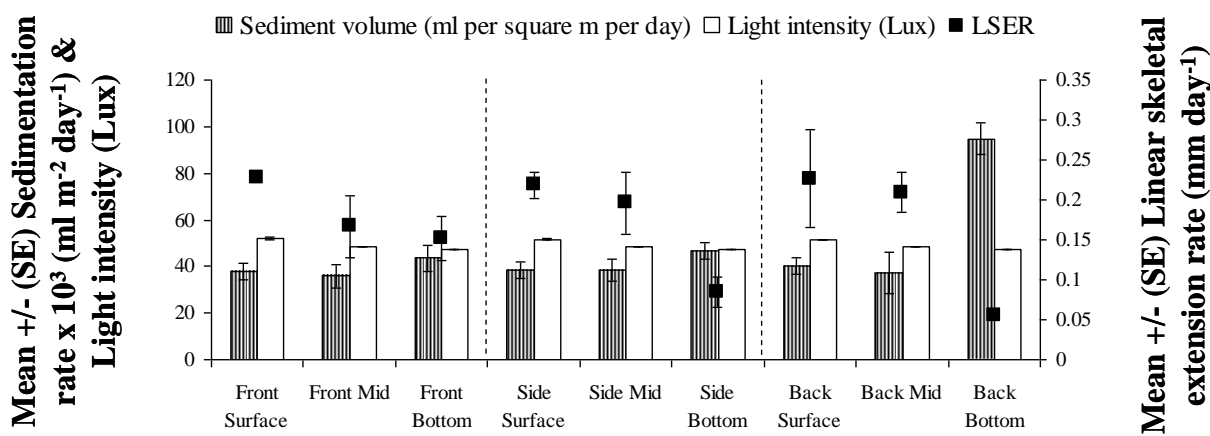

Reef sites

Figure 3. Comparisons of mean $( \pm \mathrm{SE})$ sedimentation rate $\left(\mathrm{ml} \mathrm{m}^{-2} \mathrm{day}^{-1}\right)$, light intensity (Lux) and linear skeletal extension rate (LSER) $\left(\mathrm{mm} \mathrm{day}{ }^{-1}\right.$ ) of $P$. damicornis at nine sites in a patchy reef at Polhena, Southern Sri Lanka.
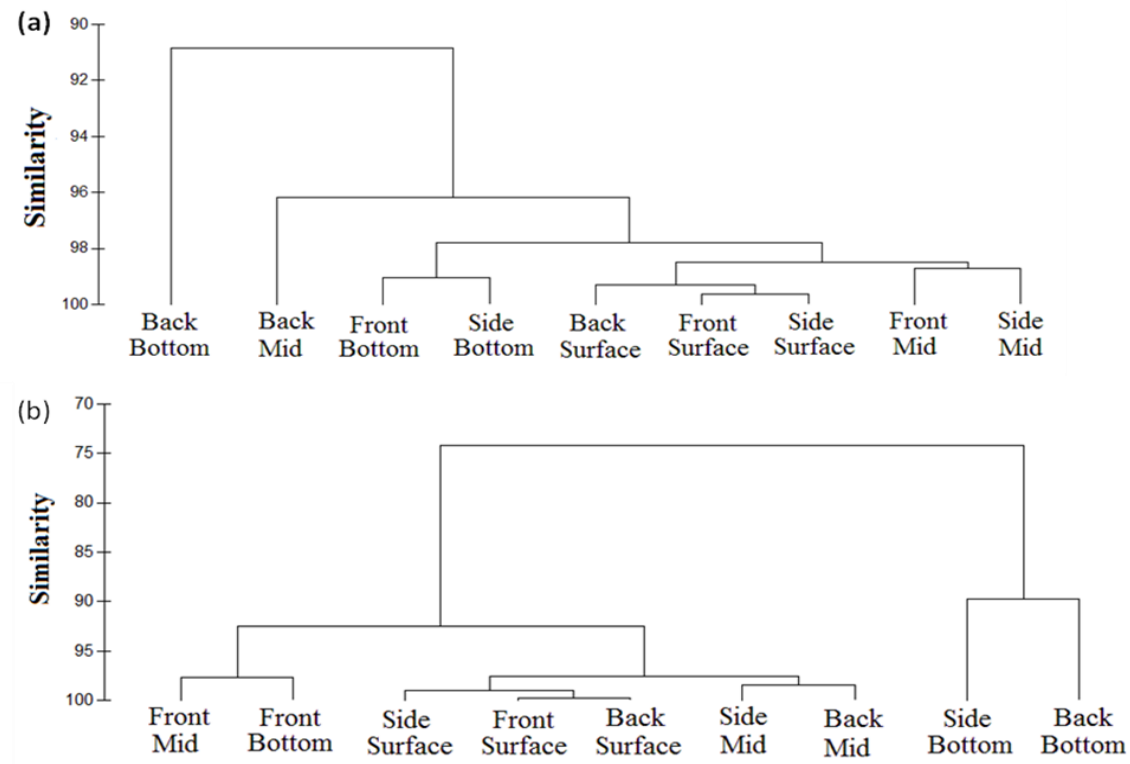

Figure 4. Bray-Curtis similarity cluster analysis showing the similarity of sites of the patchy reef when (a) all the physico-chemical parameters, and (b) linear skeletal extension rate of $P$. damicornis are considered. 
There were no significant similarities among the sites with respect to physicochemical parameters $(\mathrm{p}>0.05$; Figure $4 \mathrm{a}$ and Figure 5a), and LSER of $P$. damicornis ( $\mathrm{p}>0.05$; Figure $4 \mathrm{~b}$ and Figure $5 \mathrm{~b}$ ). The highest similarity of physicochemical conditions was observed between the sites at front surface and the side surface (99.64\%; Figure 4a), and the lowest similarity was observed among the back bottom site and the combinations of all of the other sites (90.84\%; Figure 4a). In addition, the highest similarity of the LSER of $P$. damicornis was observed between the sites at front surface and the back surface (99.76\%; Figure 4b). In contrast, the lowest similarity of LSER was observed between the sites of the side bottom with the back bottom and of all the other sites (74.24\%; Figure $4 \mathrm{~b})$.

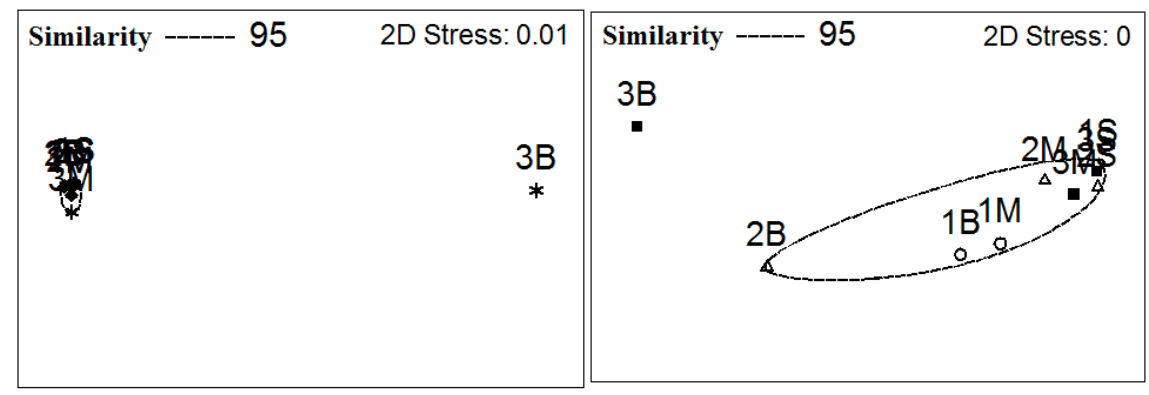

Figure 5. Two dimensional MDS ordinations with super imposed Bray-Curtis similarity clusters (ovals) at the $95 \%$ similarity level for sites $(\mathrm{O}=$ front locations, $\Delta$ $=$ side locations, and $\mathbf{m}=$ back locations, $1=$ front, $2=$ side, $3=$ back, $S=$ surface, $M$ $=$ mid, $\mathrm{B}=$ bottom) at patchy-reef studied (a) physico-chemical parameters and (b) linear skeletal extension rate of $P$. damicornis.

LSER of $P$. damicornis was negatively correlated with sediment volume, and turbidity, while positively correlated with light intensity (Table 3).

Table 3. Pearson correlation of LSER with turbidity (NTU), light intensity (Lux), and sediment volume $\left(\mathrm{ml} \mathrm{m}^{-2}\right.$ day $\left.^{-1}\right)$ in a patchy reef of Polhena, Southern Sri Lanka $(n=9)$.

\begin{tabular}{lcc}
\hline & Pearson's correlation & $\mathrm{p}$ \\
\hline Turbidity & -0.860 & $<0.005$ \\
Light intensity & 0.769 & $<0.02$ \\
Sediment volume & -0.771 & $<0.02$ \\
\hline
\end{tabular}

\section{Discussion}

Current study showed that the variation in sedimentation rate and light intensity has significant impact on growth of $P$. damicornis at different sites of the patchy reef. The growth rates of $P$. damicornis recorded in this study are nearly consistent with 
those recorded in previous studies (Mayor 1924; Mantón 1932; Glynn and Stewart 1973; Glynn et al. 1979) (Table 4). As this study included branch extensions along the diameter to both sides of $P$. damicornis colony, the actual linear skeletal extension was considered to be nearly the half of that value. However, there was a different growth rate of $P$. damicornis at different sites of the patchy reef.

Table 4. Growth rate of $P$. damicornis between different geographic locations.

\begin{tabular}{|c|c|c|c|}
\hline Location & Method & $\begin{array}{l}\text { Growth Rate } \\
\text { (cm per year) }\end{array}$ & References \\
\hline $\begin{array}{l}\text { Polhena reef, Southern } \\
\text { Sri Lanka }\end{array}$ & Real time-field & $\begin{array}{l}2.73 \pm 0.19 \\
\text { (as a diameter } \\
\text { extension) }\end{array}$ & This study \\
\hline $\begin{array}{l}\text { South West and North } \\
\text { West solitary Islands, } \\
\text { Australia }\end{array}$ & Real time-field & 12.4 & Harriot (1999) \\
\hline $\begin{array}{l}\text { Enewetak Atoll, Marshal } \\
\text { Island }\end{array}$ & Real time-field & 1.5 to 3.5 & Richmond (1987) \\
\hline Hawaii & Real time-field & $1.39 \pm 1.17$ & Edmondson (1929) \\
\hline Hawaii & Isotope uptake & 0.82 & $\begin{array}{l}\text { Clausen and Roth } \\
\text { (1975) }\end{array}$ \\
\hline Galapagos & Real time-field & 2.8 & Glynn et al. (1979) \\
\hline Panama & $\begin{array}{l}\text { Real time } \\
\text { photo. }\end{array}$ & 2.37 & $\begin{array}{l}\text { Glynn and Stewart, } \\
\text { (1973) }\end{array}$ \\
\hline Panama & $\begin{array}{l}\text { Real time } \\
\text { staining }\end{array}$ & 2.2 & $\begin{array}{l}\text { Glynn and Stewart, } \\
\text { (1973) }\end{array}$ \\
\hline Gibraltar & Real time-lab. & 2.45 & Mantón (1932) \\
\hline Samoa & Real time-field & $2.78 \pm 1.53$ & Mayor (1924) \\
\hline
\end{tabular}

The least growth rate of $P$. damicornis $\left(0.05 \pm 0.01 \mathrm{~mm} \mathrm{day}^{-1}\right)$ was observed at the back bottom site of the patchy reef (site 9 ) where the sedimentation was very high $\left(94818 \mathrm{ml} \mathrm{m}^{-2} \mathrm{day}^{-1}\right)$ and the light intensity was very low (47.27 Lux). Presence of high levels of sediment particles at the back bottom site might reduce light penetration (site 9), thus resulting in a low light intensity at that place. This conclusion is strengthened by turbidity data that showed negative correlation with LSER.

There is a trade-offs in corals in the use of energy between growth and cleaning the tissues to maintain good health. Corals have to spend large amount of energy to rid themselves of sediments coming into contact with their tissues (Crossland 1980) through secretion of mucous (Charuchinda and Hyllerg 1984). Otherwise this energy would have been used for their growth (Crossland 1980). Huge sediment loads at the back bottom site of the patchy reef could be the reason for the slower LSER of $P$. damicornis located at this site. Hermatypic P. damicornis rid themselves of sediments by mucus secretion and cilliary action, which compels the corals to use its stored energy. These settling particles and suspended material which cause high turbidity would cut off the light penetration towards the growing 
corals and reduce available light for zooxanthellae for photosynthesis. This can result in a negative impact on primary production of zooxanthellae reducing growth indirectly. Thus, it could be concluded that land-based anthropogenic activities which enhance the sediment loading into Nilwala river due to surface run-off particularly in the rainy season can cause a major impact for the growth of corals on the Polhena fringing reef in Sri Lanka.

Patterns of water movements over a patchy reef are associated with patterns of sediment accumulation. Amount of sediments gathered in the back location of the patchy reef was higher than other sites, which could be due to the reason that the elevated reef patches act as barriers for water currents carrying sediments and also due to the movement of waves, which carry large amounts of sediments, in a curvilinear path when they reach the elevated reef patches (see Figure 2). The mechanical energy of waves helps them to carry more sediments, which settle down at the back bottom site of the patchy reef due to the gravitational force, resulting in the accumulation of large amounts of sediments at the back bottom site. Moreover, curvilinear motion of the water might stir the deposited fine particles of sediments and bringing them up and re-settling again. This water current might help to create curvilinear motion of sediments at the back of the reef. The sediments that follow a curvilinear path off the bottom with the water movement over a patchy reef can settle down on to the coral colonies when there is an insufficient water movement to wash them off. It can be suggested that the bottom sites in this patchy reef are not suitable for growth of corals as there was slower LSER of corals and higher sedimentation rates. In addition, high sedimentation may negatively affect the settlement of coral larvae (Hughes et al. 1999; Pradeep Kumara 2008). The number of juvenile and adult corals inhabiting a particular location of a reef is basically determined by the availability of suitable surfaces (Pradeep Kumara et al. 2007). These bottom sites may receive sediment loads from the above water column, thus reducing the number of successful settlements and the growth of coral colonies which have already been settled. The considerably low density of coral colonies observed at the back bottom site of the patchy reef during the present study may also be due to high sedimentation. Patterns of water movements around reefs and rainfall data should also be studied to identify sedimentation dynamics on coral reefs.

Discharges and monsoonal rain alter the seawater condition at Polhena reef. Heavy rain received during south-west monsoon season (July-August) might cause low salinity (27.30 $\mathrm{mgL}^{-1}$ in July) due to river run-off. Moreover, run-off from the Nilwala river might carry huge sediment loads to the Polhena reef area thus exhibiting higher sedimentation rate $\left(54133 \mathrm{ml} \mathrm{m}^{-2} \mathrm{day}^{-1}\right.$ in July). These salinity and sedimentation stress may have reduced LSER of $P$. damicornis $\left(0.10 \mathrm{~mm}^{\text {day }}{ }^{-1}\right)$ in July. In contrast, in November there was a low sedimentation rate $\left(37389 \mathrm{ml} \mathrm{m}^{-2}\right.$ day $\left.^{-1}\right)$ and high irradiation and hence, the fast LSER $\left(0.17 \mathrm{~mm} \mathrm{day}{ }^{-1}\right)$ of $P$. damicornis was recorded. This also provide evidence for the fact that sedimentation plays an important role in determining the rate of coral growth particularly at reefs which are located close to freshwater inlets.

The current survey has recorded the overall mean sedimentation rate of 45860 $\mathrm{ml} \mathrm{m}^{-2}$ day $^{-1}\left(=1588.01 \mathrm{~g} \mathrm{~m}^{-2}\right.$ day $\left.^{-1}\right)$ during south west monsoon period from June to November. However Bandaranayake et al. (2003) recorded that the sedimentation 
rates were $2026 \mathrm{~g} \mathrm{~m}^{-2}$ day $^{-1}$ in September 2000 and $3808 \mathrm{~g} \mathrm{~m}^{-2}$ day $^{-1}$ in July 2001 at Polhena reef. During the present study the sedimentation rate at different sites and mean values were calculated considering sedimentation rate at different sites around the selected patchy reef (Figure 1). This study emphasizes that spatial and temporal patterns of sedimentation within a reef should be considered. In addition, this study highlights that analyses of the sediment volume may possibly be more accurate than measuring sediment weight in a unit area of a coral reef. The lighter the sediment particles, the larger the volume and in a unit mass of sediment, volume may be different. Furthermore, the volume of particles is more important in the light penetration to coral colony than the mass. Therefore, this study highlights that future studies on sedimentation effects on coral reefs must consider sediment volume rather than sediment weight.

\section{Acknowledgements}

Authors acknowledge the financial assistance through SIDA/SAREC Marine Science Research Grant of the Department of Fisheries Biology, University of Ruhuna, Matara, Sri Lanka.

\section{References}

Bandaranayake, A.G., P.R.T. Cumaranatunga \& M.F.M. Fairoz 2003. Impact of sedimentation and its organic matter content on two reef sites in the Southern coastal belt of Sri Lanka. Proceedings of the second international conference. Remediation of contaminated sediment 2003. 143-4.

Buddemeier, R.W. \& R.A. Kinzie 1976. Coral Growth. Oceanography and Marine Biology Annual Review 14: 183-225.

Charuchinda, M. \& J. Hylleberg 1984. Skelital extention of Acropora formosa at a Fringing Reef in the Andaman Sea. Coral Reefs 3: 215-219.

Clausen, C.D. \& A.A. Roth 1975. Effect of temperature and temperature adaptation on calcification rate in the hermatypic coral Pocillopora damicornis. Marine Biology 33: 93-100.

Crossland, C.J. 1980. Release of photosynthetically-derived organic carbon from a hermatypic coral, Acropora acuminata. 163-172 pp. In: Schwemmler W. \& H.E.A. Schenk (eds) Endocytobiology endosymbiosis and cell biology, Volume 1. de Gruyter, Berlin.

Edmondson, C.H. 1929. Growth of Hawaiian corals. Vol. 58. Bernice P. Bishop Museum, Honolulu.

Fairoz, M.F.M. 2006. Impacts of natural processes and anthropogenic activities on two fringing coral reefs of southern Sri Lanka. M. Phil. dissertation. University of Ruhuna, Matara, Sri Lanka.

Glynn, P.W. \& R.H. Stewart 1973. Distribution of coral reefs in the Pearl Islands (Gulf of Panama) in relation to thermal conditions. Limnology and Oceanography 18.3: 307-379.

Glynn, P.W., G. M. Wellington \& C. Birkeland 1979. Coral reef growth in the Galapagos: limitation by sea urchins. Science 203: 47-49. 
Goreau, T.J. 1992. Bleaching and reef community change in Jamaica: 1951-1991. American Zoologist 32: 683-695.

Hariiott, V.J. 1999. Coral growth in subtropical eastern Australia. Coral Reefs 18: 281-291.

Hughes, T.P., A.H. Baird, E.A. Dinsdale, N.A. Moltschaniwskyj, M.S. Pratchett, J.E. Tanner \& B.L. Willis 1999. Patterns of recruitment and abundance of corals along the Great Barrier Reef. Nature 397: 59-63.

Makerenth, E.J.H., J. Heran \& J.F. Talling 1978. Water Analysis: Some Revised Methods for Limnologists. Scientific Publication No. 36. Freshwater Biological Association, Ambleside. $120 \mathrm{p}$.

Mantón, S.M. 1932. On the growth of the adult colony of Pocillopora bulbosa. Museum Natural History, Great Barrier Reef Expedition 1928-1929. 3: 157166.

Mayer, A.G. 1924. Growth rate of Samoan corals. Papers from the Department of Marine Biology of the Carnegie Institute of Washington 19: 51-72.

Muscatine, L. 1990. The role of symbiotic algae in carbon and energy flux in reef corals. In: Dubinsky, Z. (ed.) Ecosystem of the World Coral Reefs. Elsevier, Amsterdam 75-87.

Öhman, M.C., A. Rajasuriya \& S. Svensson 1998. The use of butterfly fishes as bioindicators of habitat structure and human disturbances. Ambio 27: 708716.

Patterson, M. R., K. P. Sebens \& R. R. Olson, 1991. In situ Measurements of Flow Effects on Primary Production and Dark Respiration in Coral Reefs. Journal of Experimental Marine Biology and Ecology 116: 193 - 217.

Pradeep Kumara, P.B.T. 2008. Patterns of Coral Reproduction and Distribution in Southern Sri Lanka: Reef Resilience in Environment Affected by Major Disturbances. PhD Dissertation, School of Pure and Applied Natural Sciences, University of Kalmar, Sweden.

Pradeep Kumara, P.B.T., P.R.T. Cumaranatunga, \& D. Souter 2007. Spatio-temporal patterns of coral larvae settlement in three selected reefs in southern Sri Lanka. Journal of Marine Science and Environment. C5 2007: 7-12.

Rajasuriya, A., M.C. Orman \& S. Svensson 1998. Coral reef and rock reef habitats in Southern Sri Lanka. Patterns in the distribution of coral community. Ambio 27: 223-728.

Richmond, R.H. 1987. Energetic relationships and biogeographical differences among fecundity, growth and reproduction in the reef coral Pocillopora damicornis. Bulletin of Marine Science 41: 594-604.

Sokal, R.R. \& F.J. Rohlf 1969. Biometry. Freeman, San Francisco.

Veron, J.E.N. 1986. Coral of Australia and Indo-Pacific. Angus and Robertson, London. 644 p.

Wilkinsion, C.R. \& R.W. Buddemeier 1994. Global Climate Change and Coral Reef: Implications for people and Reefs. Report of the UNEP. IOC-ASPEIIUCN Global Task Team on the Implications of Climate Change on Coral Reefs. IUCN. Gland. Switzerland, 124. 